\title{
HEADINGS OF THE PLEADING DOCUMENTS IN RUSSIAN LEGISLATIVE ACTS AND REGIONAL BUSINESS WRITING OF THE $18^{\text {th }}$ CENTURY
}

\author{
Svetlana V. Rusanova \\ Novosibirsk State Technical University, Novosibirsk, Russia
}

\begin{abstract}
The article is aimed at studying changes in the title of pleading documents of the $18^{\text {th }} \mathrm{cen}$. Due to a comparative analysis of language specificity of Russian legislative acts and regional business documentation of the $18^{\text {th }}$ cen. some differences in the system of descriptive heading were noticed and referred to constant features of this genre of business writing. It is pointed that the texts under analysis might be divided into two groups applications which call for a judicial decision and the ones that do not require it. In the focus of linguistic analysis the changes in the titles of the pleading text are. The analysis of central and regional documents revealed some asymmetry in the usage of descriptive headings. It is evident that until the end of the $18^{\text {th }}$ cen. the title chelobitnaya was used to head a private pleading, which was inherited from the prikaz letter style, but could be specified with modifiers like iskovaja, mirovaja, javochnaja, apelljacionnaja. It is proved that due to the time span in the regional business writing a chelobitnaya heading demonstrates decrease in its usage and its specialization is presented in some newly coined equivalents. By the end of 80 -s $\left(18^{\text {th }}\right.$ cen.) the tendency of the heading alignment in the applications that require judicial decisions is noted which may be explained by the Imperator order to keep it out of the documentation norms.

Key words: Russian language history, business language, business language of the $18^{\text {th }}$ cen., document genre, legislative act, regional writing, pleading document, chelobitnaya.

Citation. Rusanova S.V. Headings of the Pleading Documents in Russian Legislative Acts and Regional Business Writing of the $18^{\text {th }}$ Century. Vestnik Volgogradskogo gosudarstvennogo universiteta. Seriya 2. Yazykoznanie [Science Journal of Volgograd State University. Linguistics], 2019, vol. 18, no. 2, pp. 16-26. (in Russian). DOI: https://doi.org/10.15688/jvolsu2.2019.2.2
\end{abstract}

\section{НАИМЕНОВАНИЯ ПРОСИТЕЛЬНЫХ ДОКУМЕНТОВ В ЗАКОНОДАТЕЛЬНЫХ АКТАХ И РЕГИОНАЛЬНЫХ ДОКУМЕНТАХ ХVIII ВЕКА}

\author{
Светлана Владимировна Русанова \\ Новосибирский государственный технический университет, г. Новосибирск, Россия
}

Аннотация. Объектом исследования избраны просительные документы XVIII века. В результате сопоставительного изучения языка законодательных актов и региональных памятников XVIII в. были обнаружены некоторые особенности в их наименовании. Установлено, что ключевым для жанровой характеристики просительных документов рассматриваемой эпохи является их деление в зависимости от функциональной направленности на две группы: требующие и не требующие судебного решения проблем, в них изложенных. Особое внимание в статье уделено наименованию челобитных, связанных с судебным решением проблем. В процессе анализа языка центральных и региональных документов за- 
фиксирована асимметрия в используемой терминологии. Выявлено, что в законодательных бумагах вплоть до конца столетия в качестве видовых наименований частных прошений использовался унаследованный из приказного письма термин челобитная, который мог уточняться определениями исковая, мировая, явочная и появившимся позже других - апелляционная. Показано, что в региональной деловой письменности отражается постепенная специализация термина челобитная и его замена в отдельных случаях новыми лексическими эквивалентами. Тенденция к выравниванию в законодательных и региональных документах терминов, обозначающих просительные документы, связанные с судебным решением споров, актуализируется в конце 80-х гг. XVIII столетия в связи с императорским указом об исключении термина челобитная из документооборота.

Ключевые слова: история русского языка, деловой язык, деловой язык XVIII века, документный жанр, законодательный акт, региональная письменность, просительный документ, челобитная.

Цитирование. Русанова С. В. Наименования просительных документов в законодательных актах и региональных документах XVIII века // Вестник Волгоградского государственного университета. Серия 2 , Языкознание. - 2019. - Т. 18, № 2. - C. 16-26. - DOI: https://doi.org/10.15688/jvolsu2.2019.2.2

\section{Введение}

Совершенствование делопроизводства в начале XVIII в. требовало преобразования приказной жанровой системы и терминологии, ее обслуживающей. Изучение этих изменений сопряжено с определенными трудностями, в частности, с необходимостью учитывать актуальные в период формирования делового языка нового типа быстроту эволюционных процессов и характер взаимоотношения гетерогенных языковых средств: приказных, разговорных, книжно-славянских, заимствованных (прежде всего из западноевропейских языков).

Благодаря исследованиям последних десятилетий в области делового языка XVIII в. создан ряд классификаций жанров деловой письменности, отличающихся принципами систематизации документных текстов и позволяющих воссоздать многоаспектную картину их функционирования [Выхрыстюк, 2008; Гауч, 2013; Глухих, 2008; Горбань, Шептухина, 2013; Копосов, 2000; Косов, 2004; Майоров, 2004; 2006; Малышева, 1997; Никитин, 2000; Трофимова, 2002; Юнаковская, 2014], что дает возможность, с одной стороны, остановиться на более частных, но менее изученных вопросах жанрообразования, с другой обнаружить некоторые тенденции и закономерности в формировании и совершенствовании терминологической системы делового языка рассматриваемого периода. Актуальным является сопоставительное изучение языкового материала законодательных актов и региональной документации.

\section{Челобитная в законодательных актах XVIII в.: особенности семантики и функционирования термина}

Одним из главных путей совершенствования жанровой системы в Петровскую эпоху является вытеснение старых жанров новыми и, как следствие, введение в речевой оборот терминов, чаще всего заимствованных. Так появились промемории, инструкции, ордера, рапорты (репорты), квитанции, дипломы и др. Однако на фоне интенсивного образования и введения в канцелярское делопроизводство новых жанров нельзя не отметить факт сохранения наряду с ними отдельных приказных жанров вместе с их прежними наименованиями. К таковым относится челобитная, удерживающая ключевые позиции в жанровой системе вплоть до конца XVIII столетия. Из активного употребления челобитная выходит под влиянием изданного Екатериной II в 1786 г. закона об исключении из формуляра челобитных таких слов и устойчивых выражений, как бьет челом, челобитье, челобитная и замене их словами просит, прошение, приносит жалобу; само же просительное заявление рекомендуется именовать прошением или жалобницей (ПСЗ, т. ХХІІ, № 16.329). В связи с этим следует признать исторически устаревшей лексикографическую традицию, ограничивающую функционирование данной разновидности документов началом XVIII в., а место их подачи - приказами [Русанова, 2016].

Термин челобитная в деловом языке XVIII в., как и в предыдущий период [Волков, 1974], выступает и родовым наименова- 
нием группы просительных актов, и видовым названием искового заявления, и эквивалентом видовых двучленных наименований разновидностей челобитных. Однако за внешним структурным сходством канцелярского термина с приказным обнаруживаются лексикосемантические различия. Не все разновидности челобитных сохранили свою актуальность в канцелярском делопроизводстве. Ядро составили документы, связанные с судебным решением споров: исковая, мировая, апелляционная и явочная челобитные ${ }^{1}$. Причем, как свидетельствуют памятники, в наименовании данных разновидностей просительных документов в законодательных актах и региональных документах не обнаруживается тождества.

Для языка законодательных актов было характерно унифицированное обозначение всех разновидностей просительных документов приказным термином челобитная. Показательными в этом плане являются указы, посвященные титулам императоров (ПС3, т. VII, № 4755, 1725 г.; т. VII, № 5071, 1727 г.; т. VIII, № 5501, 1730 г.; т. XI, № 8475, 1741 г.; т. XVI, № 11.590, 1762 г.): на протяжении почти всего XVIII столетия среди основных документов, которые должны были оформляться на имя императора, называется челобитная - без уточнения какой-либо функциональной специфики, в то время как в других нормативных актах, начиная с петровских указов, термин челобитная стабильно используется как эквивалент двучленных наименований исковых, мировых, явочных и апелляционных прошений. Сравните примеры употребления термина для обозначения вышеперечисленных просительных документов в указах разных лет.

\section{Исковая челобитная:}

(1) которые истцы всякихъ чиновъ люди, впредь съ сего Его Великаго Государя указу, учнуть приносить исковыя челобитныя на ответчиковъ во всякихъ своихъ обидахъ о допросе: и темъ челобитчикамъ велеть въ челобитныхъ своихъ писать прямое дело, о чемъ они бьютъ челомъ, а лишняго и посторонняго ничего не писать (ПС3, т. IV, № 1806 , с. 73,1700 г.) ${ }^{2}$;

(2) А потомъ те челобитныя съ помянутымъ подписаниемъ подавать къ пометамъ судьямъ, и по ответчиковъ посылать, какъ надлежить; <.. > когда вычтена будетъ исковая челобитная, прежде запис- ки допроса велеть подписываться противъ того жъ (ПСЗ, т. V, № 3251, c. 600, 1718 г.);

(3) чтобъ всемъ Ея Императорскаго Величества вернымъ подданнымъ, каждому о своей обиде, такожъ и о прочихъ всякихъ делахъ бить челомъ въ надлежащихъ местахъ, а на неправое решение и на волокиту Коллегий и Канцелярий; бить челомъ въ Сенате, $<\ldots$.. >, и въ окончании оныхъ челобитенъ писцамъ писать чинъ свой и имя и где надлежить подать (ПСЗ, т. XV, № 10.980, с. 366, 1759 г.);

(4) Выслушавъ и разсмотревъ прошение его, ежели дело найдется принадлежащее не къ Намъ, а къ какому либо судебному месту, вышнему или нижнему, то оное на той же челобитной подписавъ съ именемъ своимъ, каждому челобитчику возвращать имеете съ темъ, чтобы проситель сь тою надписью въ то место, куда его дело принадлежитъ, неотменно самъ подалъ (ПСЗ, т. XVI, № 11.868, c. 303,1763 г.).

\section{Апелляционная челобитная:}

(5) у челобитчиковъ всякихъ чиновъ людей, челобитенъ такихъ, которыя будутъ бить челомъ на Коллегии и Канцелярии (кроме подчиненныхъ къ Коллегиямъ), въ которыхъ написано не будетъ, что вершено неправо, не принимать, а велеть писать въ челобитныхъ, что вершено неправо и противно указу, а какая неправость и противность указамъ, о томъ въ техъ челобитныхъ описывать именно (ПСЗ, т. VI, № 3643, с. 239, 1720 г.);

(6) Ежели въ Ратуше какое дело будетъ решено не право, то на Бурмистровъ челобитныя принимать, и неправо вершенныя дела для разсмотрения брать и вершить по Уложенью и указамъ (ПСЗ, т. VIII, № 5333, с. 98,1728 г.);

(7) а на Коллежския неправыя решения бить челомъ въ Сенате, и подавать челобитныя определенному для того Генералъ-Рекетмейстеру; противно же того никому ни о какихъ своихъ делахъ, принадлежащихъ до расправы того учрежденнаго правительства, Самой Ея Императорскому Величеству челобитенъ отнюдь не подавать (ПСЗ, т. Х, № 7599 , c. 539,1738 г.);

(8) и впредь подаваемыя отъ Малороссиянъ на Генеральную Войсковую и Министерскую Канцелярии, какъ въ долговременномъ нерешении, также и въ неправомъ решении делъ ихъ челобитные принимать Генералу-Рекетмейстеру (ПС3, т. XII, № 9285, с. 546, 1746 г.);

(9) и буде где въ чемъ дело будетъ решено неправильно, то которымъ Межевой инструкции пунктовъ въ противность, объявлять именно, безъ чего и челобитенъ не подавать (ПСЗ, т. XIV, № 10.669, c. 696,1756 г.);

(10) На решенныя жъ съ сего времени дела апеллячионныя челобитныя подавать, считая оть 
дня объявления решительнаго определения, всемъ находящимся внутри Государства полагается сроку одинъ годъ (ПСЗ, т. XVI, № 11.629, с. 30, 1762 г.).

\section{Явочная челобитная:}

(11) Съ явочныхх челобитенъ, которыя подаютъ о всякихъ делехъ для записки, пошлинъ имать по 4 деньги с челобитной (ПС3, т. IV, № 1743, с. 2, 1700 г.);

(12) Съ подаваемыхъ во всехъ местахъ челобитенъ явочныхъ по 25 копеек, исковыхъ по 3 рубли, а апелляционныхъ по 6 рублей брать во всехъ техъ местахъ, и въ то время, где оныя по принадлежности поданы будутъ; но изъ сего исключаются явочныя челобитныя, подаваемыя въ убивствахъ, въ разбояхъ и въ грабежахъ (ПСЗ, т. XVI, № 11988, c. 460,1763 г.).

\section{Мировая челобитная:}

(13) Которыя всякия вышеписанныя крепости меньше 50 рублевъ и челобитныл мировыл на площади, или где инде писать, на бумаге, которая подъ гербомъ величиною противъ золотаго (ПСЗ, т. III, № 1703, с. 650, 1699 г.);

(14) Понеже, по Уложению 10 главы, по 121 пункту: которые истцы и ответчики, учнутъ мириться до вершения судныхъ делъ, и имъ о томъ велеть, къ суднымъ деламъ подавать мировыя челобитныля за своими руками (ПСЗ, т. IX, № 6845, с. 654, 1735 г.);

(15) Которыя истцы и ответчики, по розыскнымъ деламъ, до подлиннаго розыска, и до вершения техъ делъ, межъ собою мирятся, и приносять челобитныя, а въ техъ челобитныхъ пишутъ, что они межь собою розыскався, ни на кого не челобитчики (ПСЗ, т. IX, № 6845, с. 655, 1735 г.);

(16) однако же до разсмотрения и решения оными вступитъ отъ техъ тяжущихся мировое челобитье, что они по тому делу между собою помирились (ПСЗ, т. ХХІ, № 15.553, с. 712, 1782 г.).

Рубежным в законодательной регламентации вышеперечисленных терминов был указ от 19 июля 1764 г. «О сборах с явочных, апелляционных и исковых челобитен», утвержденный Екатериной Великой на заре ее правления (ПС3, т. XVI, № 12.210). Будучи формально связанным с одной из статей государственного дохода - сбором пошлин с челобитных, указ содержит систематизированное лексикографическое описание функциональных разновидностей просительных документов того времени, связанных с судебным решением споров:

(17) 1. Явочныя, которыми челобитчики, о чемъ бы то ни было, изъявляютъ впредь для своей очистки или для иска. 2. Апелляционныя, те, которыми просятъ о переносе решенныхъ делъ изъ одного Судебнаго места в другое Вышнее. 3. Исковыя, единственно те, коими челобитчики ищуть исковъ, то есть, штрафовъ, какъ за причиненныя имъ обиды, такъ и за держание беглыхъ людей, пожилыхъ летъ, и за владенныхъ денегъ, за завладенныя жъ, какъ земли, такъ всякия пожитки и вещи, равнымъ образомъ с заемныхъ денегъ процентовъ и рекамбиевъ и прочихъ званиевъ исковыя челобитныя, по которымъ, какъ по Уложенью 10 главы 100, 101 и 102 пунктамъ, и по указу о Форме Суда 1723 года, у истцов с ответчиками суда производятся (ПСЗ, т. XVI, № 12.210 , с. 842$)$.

Из просительных документов, связанных с необходимостью судебных действий, не нашла отражения в указе лишь мировая челобитная, примыкающая к названным просительным документам по своему назначению. Это объясняется, по-видимому, тем, что указ был посвящен только челобитным, с которых следовало иметь «новоположенный сборъ» (ПС3, т. XVI, № 12.210, с. 842).

Исследуемые термины вытесняются из языка законодательных документов после упомянутого именного закона 1786 г.: вместо исковая челобитная, явочная челобитная, апелляционная челобитная и мировая челобитная начинают использоваться исковое прошение, явочное прошение, апеллячионное прошение и мировое прошение. Ср., в указе от 23 июня 1794 г.:

(18) Установленныя до сего времени пошлины с просительных дел, за печати восковыя, печатныя пошлины, с прошений исковых, явочных и апелляционных, кроме мировых, с патентов и жалованных грамот собирать вдвое противу настоящаго (ПС3, т. XXIII, № 17.226, с. 533).

\section{Челобитная в региональной деловой письменности XVIII века}

В региональном деловом письме в наименовании исследуемых просительных документов представлена несколько иная картина - постепенная специализация термина челобитная и замена в отдельных случаях приказного наименования новыми лексическими одночленными эквивалентами. Данная замена встраивала просительные документы в формирующуюся жанровую систему нового типа, которая отличалась более жесткой вер- 
бальной дифференциацией смежных разновидностей просительных документов на функциональной основе.

Семантическое пространство термина челобитная к середине XVIII в. сужается, он продолжает использоваться в региональных документах как наименование только исковой и мировой челобитных, обязательно оформлявшихся на имя императора и писавшихся на гербовой бумаге [Русанова, 2012]. В этих просительных документах сохраняется унаследованная из приказного письма черта, отличающая их от других видов канцелярской документации, просительных в том числе, отсутствие в структуре документа самоназвания, которое обнаруживалось обычно лишь в казусной части или в формуле прошения. Именно эти две разновидности просительных документов сохранили почти до конца столе- тия разработанный еще в правление Петра I и совершенствуемый при каждом новом правителе формуляр с обязательным набором этикетных средств в формуле обращения к монарху. Приведем в качестве примеров фрагменты ключевых формул исковой и мировой челобитных из забайкальских архивных фондов $^{3}$ (см. таблицу).

Судя по региональным документам, терминологическое и соответственно жанровостилистическое размежевание исковой и явочной челобитных завершилось к середине столетия, что находит отражение в лексическом маркировании последней, которая с этого времени приобретает самоназвание объявление. Получив широкое распространение во 2-й половине XVIII в., объявление представляло собой «писменное извещение о чемъ въ какое либо судебное место» (САР, т. VI, стб. 1029).

\begin{tabular}{|c|c|}
\hline Исковая челобитная 1755 г. & Мировая челобитная 1785 г. \\
\hline 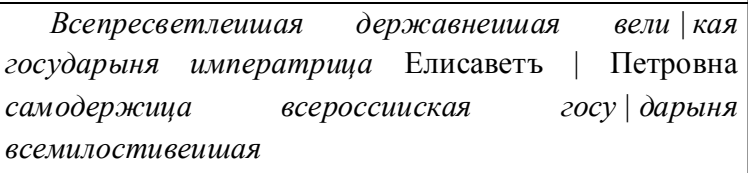 & $\begin{array}{l}\text { Всепресветлейшая державнешиая |великая государыня } \\
\text { императрица } \mid \text { Екатерина Алексеевна самодержица } \mid \\
\text { всеросииская государыня всемилостивечиая }\end{array}$ \\
\hline $\begin{array}{l}\text { Бьет челом нерчинского ведомства Нижнеи } \\
\text { Сретенскои } \mid \text { церкви с[вя]щенникъ Андреи Стефановъ } \\
\text { того ж Сретен } \mid \text { ского ведомства отставного казака } \\
\text { Стефана Лонша } \mid \text { кова а в чем мое челобитье тому } \\
\text { следуют пункты: <..> }\end{array}$ & $\begin{array}{l}\text { Бьет челомь Ильинского острогу мещанинъ Тихонъ } \\
\text { купцы |Михаило и Григореи и нерчинскои мещанинъ } \\
\text { Иванъ Михаиловы дети |Кандаковы а о чемъ тому } \\
\text { следуютъ пункты <... }\end{array}$ \\
\hline $\begin{array}{l}\text { И дабы высочаишимь Вашего Императорскаго | } \\
\text { Величества указом повелено было сие мое } \\
\text { челобит [ь]е | в Нерчинску к Заказным духовнаго } \\
\text { правления деламъ принять и в вышеписанном ево | } \\
\text { реченным Лоншаковым у меня лошади и в брани и в } \\
\text { назывании меня вором | учинить какъ Вашего } \\
\text { Императорскаго Вели | чества правы повелевають }\end{array}$ & $\begin{array}{l}\text { И дабы высочаимимь Вашего Императорскаго } \\
\text { Величества указомь повелено было сие наше } \\
\text { челобит }[\text { ь }] \text { | } \mid \text { принять и нась именованны }{ }^{\mathrm{x}} \text { от того дела } \\
\text { уволить и учинить | милостивую резолюцию }\end{array}$ \\
\hline $\begin{array}{l}\text { Всемилостивеишая государыня прошу|Вашего } \\
\text { Императорскаго Величества о сем|моем челобитье } \\
\text { решение учинить июня дня } \mid 1755 \text { года к поданию } \\
\text { надлежит в Нерчинскъ к Заказным | духовнаго } \\
\text { правления делам челобитную писал Нерчи } \mid \text { нскои } \\
\text { воеводскои канцелярии подканцеляристь Илья } \\
\text { Малцовъ |к подлиннои челобитнои с[вя]щенникъ } \\
\text { Андреи Стефанов руку при|ложиль: } \\
\text { (ПЗДП, 76, л. 89-89 об.) }\end{array}$ & 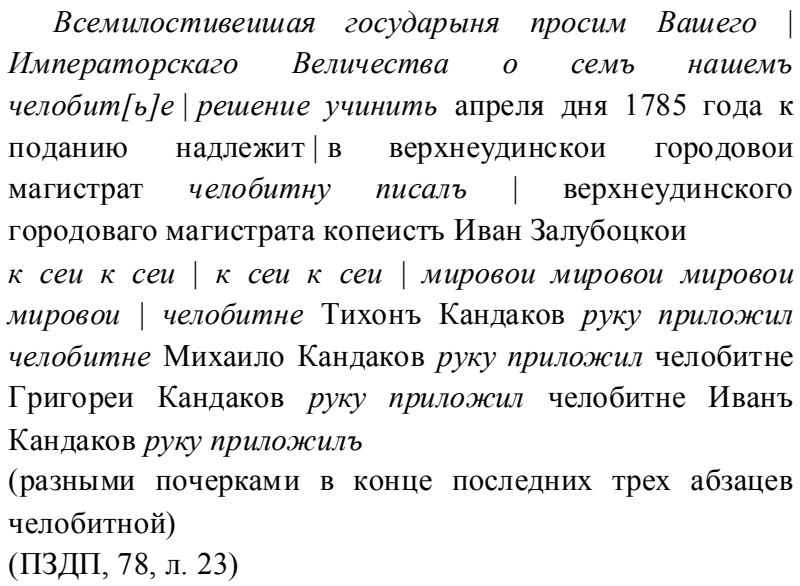 \\
\hline
\end{tabular}


Исследуя региональную деловую письменность XVIII в., А.П. Майоров определяет данную разновидность документов как «заявление о неправомерных действиях или угрозе их осуществления по отношению к истцу; документ, содержащий такое заявление» (СРЯВС3, с. 287). А.Г. Косов, опираясь на южно-уральские архивные материалы, акцентирует внимание на двух подтипах объявлений: заявлениях о пропаже «собственных пожитков» (вещей, домашнего скота) или бегстве крепостных и просьбах пропустить через таможню приказчиков и работников для продажи товаров в разных городах [Косов, 2004$, c. 81$]^{4}$.

Будучи официальным заявлением истца о неправомерных по отношению к нему поступках и являясь, по сути, основанием для последующих следственных действий и обращения потерпевшего в суд с исковой челобитной, объявление не заменяло последнюю. Функциональная специализация жанра закрепляется вербально - в преобразовании формуляра, изменении классического для челобитных набора этикетных средств.

Объявление подается не на имя императора, а на имя местных органов власти (реже их представителей), формула обращения к которым - это непредикативная конструкция, включающая имя адресата в форме винительного или дательного падежа, имя адресанта в форме родительного падежа и самоназвание документа, обычно расположенное по центру. Ср.:

(19) В Удинскую коменданскую канцелярию кяхтинского купца |Петра Семенова с[ы]на | об[ъ]явление (ПЗДП, 80, л. 302, 1772 г.);

(20) Вверхнеудинским полицейским | делам Верхнеудинского уездного казначей | ства от присяжного лейбгвардии | Преображенского полку сержанта | Василья Поспелова | об[ъ]явление (ПЗДП, 82, л. 3,1790 г.);

(21) В Селенгинскую земскую избу | селенгинскаго мещанина Максима Власова $\mid$ об[ъ]явление (ПЗДП, 83, л. 2, 1797 г.); Геодезии сержанту Васил[и]ю Кожевникову | кабанского мещанина Алексея Смирных | объявление (ПЗДП, 81, л. 7, 1788 г.).

После подробного изложения обстоятельств дела, послуживших причиной написания объявления, следует формула просьбы, включающая по сути две просьбы: о регистрации заявления и проведении органами власти в соответствии с законом необходимых действий для удовлетворения просителя. Данная формула вводится сложным, книжно-славянским по происхождению союзом того $p a d u$, актуализирующим причинно-следственные связи; ключевыми в ней оказываются перформативы объявляю и прошу, причем последняя обязательно сопровождается этикетным наречием покорно / покорнейше, коммуникативно мотивированным, направленным на усиление модальности просьбы. Следует отметить, что в зависимости от статуса составителя регионального документа начальный элемент формулы того ради может замещаться вариантными по сему, о чем, перформативный глагол объявляю пропускаться, а в самой формулировке просьбы может отсутствовать указание на необходимость регистрации заявления ${ }^{5}$. Ср.:

(22) Того ради Верхнеудинские полицейския дела покорно прошу выше озна | ченных мещанъ Колоколова и Шепого | рова сыскать и в причинении жене моей Колоколловым обиде а Шепогоро | вымъ в произнесении къ зажигатель | ству речей спросить (ПЗДП, 82, л. 3 об., 1790 г.);

(23) Того ради Удинскои коменданскои канцелярии сим об[ъ] являю | и покорно прошу сие мое об[ъ]явление до изыскания тех злодеев | и грабителеи записать; а при томъ и повелено б было к тому | изысканию тех разбоиников не сыщется л кто либо паче чаяния | в таковом же грабителстве и не будут ли поиманы по ни | зовым острогамъ в земские приказные избы предложить |да и в Селенгинскую воеводскую канцелярию сообщить с тем | егда таковые воры поиманы будуть то б и о моих пограбле |нных пожитках и товарах спрашиват[ь], да егда и я сыскиват[ь] | и наведыватца оных буду то б мне чинить в том вспомо $\mid$ жение о чемъ от меня и по главнои своеи команде где надле $\mid$ житъ прошено быть имееть < ...> (ПЗДП, 80, л. 307 об., 1772 г.);

(24) о чемъ Селенгинскои | земскои избе симъ и об[ъ]являю. а какъ я от покражи | у меня значущаго по приложенному у сего на обороте $\mid$ регистру, денегъ и вещеи пришель в крайнее раззо $\mid$ рение /: такъ что и в платеже казенных и народскихъ | податеи ныне нахожу себя не в силахъ:/ то по сему | и по вышеизъясненнымъ обстоятелствамъ покорнеи $\mid$ ше прошу об отыскивании имению моему похити | телеи и о удоволствии меня куда следуетъ | представить. на что и ожидаю милостивои резолюцыи (ПЗДП, 83, л. 2-4, 1797 г.). 
Заключала объявление единая для просительных документов формула рукоприкладства: к сему объявлению ... руку приложил или подписуюсь:

(25) К сему об[ъ]явлению прошение Федора Ка | закова Иванъ Бунзиков руку приложиль (ПЗДП, 79 , л. 57,1755 г.);

(26) Кяхтинскои купец Петръ Захаров руку приложил (ПЗДП, 80, л. 307 об., 1772 г.);

(27) К сему об[ъ]явлению Алексеи Смирныхъ | подписуюсь (ПЗДП, 81, л. 7 об., 1788 г.).

Отдельного комментария требует эволюция наименования апелляционной челобитной. На данном этапе исследования региональной деловой письменности мы, к сожалению, не обладаем достаточным материалом, позволяющим говорить об особенностях изменения наименования и формуляра данной разновидности челобитных. Представляя собой «жалобу в высший суд на решение низшего» (СРЯ XVIII, вып. 1, с. 78), апелляционная челобитная почти не встречается в местном делопроизводстве, в связи с чем ее жанрово-стилистические параметры остаются малоизученными. Упоминание об апелляционных челобитных нам встретилось только в исследовании М.С. Выхрыстюк. В систематизированном списке жанрового состава документов исторического фонда И-31 Тобольской управы благочиния второй половины XVIII в. отмечается 15 апелляций, однако без дальнейшего их описания [Выхрыстюк, 2008, с. 218].

Как свидетельствуют законодательные акты первой половины столетия, жалобы в высший суд на неправое решение нижнего суда именовались просто челобитными, оформлялись они, как и исковые челобитные, на имя императора и подавались в коллегии на неправое решение подчиненных им канцелярий и контор и в сенат специально определенному для этого должностному лицу - генерал-рекетмейстеру - на волокиту самих коллегий и не подчиненных им канцелярий (ПС3, т. VI, № 3643, 1720 г.; т. VI, № 3900, 1722 г.; т. X, № 7599, 1738 г.). В нормативных бумагах второй половины столетия жалобы начинают именоваться апелляционными челобитными и апелляциионными прошениями. При этом следует сказать, что с начала века деловому языку известен термин апелляция. Словарь русского языка XVIII в. отмечает у него два значения: «жалоба в высший суд на решение низшего»; «высший суд, имеющий право решения обжалованных дел» (с пометой nол. apellacya) (СРЯ XVIII, вып. 1, с. 78). В качестве аспекта значения (или применения) в конце словарной статьи фиксируется также значение «перерешение дела, решение дела в высшей инстанции» (СРЯ XVIII, вып. 1, с. 78). Нам представляется, что на раннем этапе заимствования лексеме апелляция было свойственно именно процессуальное значение: она обозначала не жалобу, а подачу жалобы, перенос дела в высший суд, о чем свидетельствуют синтагматические связи, в частности, с глаголом чинить:

(28) И решить <провинциальным канцеляриям> маловажныя дела, не дозволяя и аппелляции чинить на них в высший суд (СРЯ XVIII, вып. 1, с. 78).

Сравните аналогичные сочетания, частотные в деловых документах XVIII в.: чинить розыск, чинить исполнение, чинить cсоры и драки и т. д. Это подтверждается и более широким контекстом употребления слова в законодательных бумагах. Так, в Наставлении губернаторам от 1764 г. читаем:

(29) Если же по апелляц̧ии будутъ прошении на неправое какъ Канцелярии, такъ и самого Губернатора решение, въ Юстицъ или въ другихъ Коллегияхъ, и дело то туда перенесется: то оныя Коллегии, увидя неправость, накладываютъ штрафъ по указамъ на одну только Канцелярию, а о Губернаторе представляють Сенату (ПС3, XVI 12.137, с. 717).

Показательным является еще один факт: относительное прилагательное апелляиионный (апелляционная челобитная, апелляционное дело) входит в деловую практику в первой половине шестидесятых годов; в Словаре русского языка XVIII в. самое раннее употребление слова относится к 1764 г. (СРЯ XVIII, вып. 1, с. 78).

\section{Заключение}

Таким образом, исследование процессов становления и функционирования в XVIII в. терминологии, обслуживающей просительные документы, связанные с судебным решением споров, позволяет обнаружить следующие особенности. Унаследованная из приказного 
языка система просительных документов подвергается серьезной трансформации: формируются новые жанры, преобразуется формуляр, осваивается новый этикет, меняются названия. Причем в законодательных актах и региональном письме в наименовании просительных документов не обнаруживается тождества. Сохраняющаяся в законодательных бумагах почти на протяжении всего столетия приказная традиция именовать все разновидности просительных документов родовым термином челобитная в делопроизводственной практике к середине века обнаруживает тенденцию к вербальной дифференциации их функциональной специфики, в частности к актуализации термина объявление, заменившего термин явочная челобитная. Выравнивание в законодательных и региональных документах терминологии, обозначающей просительные жанры, связанные с судебной деятельностью, происходит в конце 80-х гг. XVIII столетия в связи с указом об исключении из документооборота термина челобитная.

\section{ПРИМЕЧАНИЯ}

\footnotetext{
${ }^{1}$ В круг просительных документов, кроме челобитных, по которым требовались судебные решения, входили изначально также челобитные, не требующие судебной защиты прав и законных интересов. Сравните в сенатском указе 1764 г.: а челобитенъ таковыхъ, коими челобитчики просять правосуднаго возвращения себе, или о справке за ними имь законно-принадлежащяго, или же о какомъ либо себя защищении, или пранадлежащзаго (sic!) себе ко исправлению своихъ должностей, яко заслуженнаго жалованья, чину и увольнения оть службы и прочихъ званиевъ, по которымъ судовъ не производится, исковыми не почиmamь (ПС3, т. XVI, № 12.210, с. 842). Подобные просительные документы заслуживают отдельного внимания и поэтому в рамках настоящего исследования не рассматриваются.

${ }^{2}$ Графика деловых текстов XVIII в. приводится в соответствии с современной. При цитировании региональных источников выносные буквы пишутся в строке без выделения, титла раскрываются, восстанавливаемые при этом буквы даются в квадратных скобках.

${ }^{3}$ Цитируемые региональные памятники входят в состав фондов двух архивов: Государственного архива Читинской области и Национального архива Республики Бурятия.
}

${ }^{4}$ Данные Словаря русского языка XVIII в. и его картотеки, а также словарей, созданных в XVIII столетии, позволяют говорить об употребительности лексемы объявление, на что указывает обилие контекстов, в которых функционирует слово, разнообразие его синтагматических связей и значений (Вейсман, 1731, с. 9, 22, 163, 400, 414; КС СРЯ XVIII; Новой лексикон, 1755, с. 215, 609, 631, 709, 963; CAP, т. VI, c. 1028-1029; СРЯ XVIII, вып. 16, с. 137). Так, Словарь XVIII в., выделяя у слова пять значений, по сути, фиксирует десять, среди которых два специальных, связанных с деловым языком: «донос, показание», «документ, содержащий сведения о товаре; таможенная декларация» (СРЯ XVIII, вып. 16, с. 137). Материалы региональной деловой письменности, как видим, свидетельствуют еще как минимум о двух специальных значениях объявления.

5 Частый пропуск в просительной формуле просьбы о регистрации заявления объясняется тем, что жанр объявления по определению предполагал регистрацию сделанного заявления.

\section{СПИСОК ЛИТЕРАТУРЫ}

Волков С. С., 1974. Лексика русских челобитных XVII века. Формуляр, традиционные этикетные и стилевые средства. Л. : Изд-во Ленингр. ун-та. 164 с.

Выхрыстюк М. С., 2008. Тобольская письменность XVII-XVIII вв. в аспекте лингвистического источниковедения и исторической стилистики : дис. ... д-ра филол. наук. Челябинск. 558 с.

Гауч О. Н., 2013. Жанровое своеобразие организационно-распорядительных документов деловой письменности XVIII в. (на материале ТФГАТО) // Научный диалог. № 5 (17). C. 221-233.

Глухих Н. В., 2008. Деловой эпистолярный текст конца XVIII - начала XIX в. на Южном Урале: лингвистика текста. Челябинск : ПолиграфМастер. 169 c.

Горбань О. А., Шептухина Е. М., 2013. Региональные документы XVIII века: аспекты лингвистического описания // Вестник Волгоградского государственного университета. Серия 2, Языкознание. № 3 (19). С. 76-84.

Копосов Л. Ф., 2000. Севернорусская деловая письменность XVII-XVIII вв. (орфография, фонетика, морфология). М. : Народный учитель. $287 \mathrm{c}$.

Косов А. Г., 2004. Эволюция документных жанров XVIII века: На материале рукописных и печатных текстов Объединенного государственного архива Челябинской области : дис. ... канд. филол. наук. Челябинск. 273 с. 
Майоров А. П., 2004. Просительные документы XVII-XVIII вв. Лингвоисточниковедческий аспект // Palaeoslavica: International Journal for the Study of Slavic Medieval Literature, History, Language and Ethnology. Cambridge (Mass.) : Palaeoslavica. XII/2. P. 198-213.

Майоров А. П., 2006. Очерки лексики региональной деловой письменности XVIII века. М. : Азбуковник. 263 с.

Малышева И. А., 1997. Памятники деловой письменности XVIII в. как объект лингвистического источниковедения. Хабаровск : Изд-во Хабар. пед. ун-та, 1997. 182 с.

Никитин О. В., 2000. Русская деловая письменность как этнолингвистический источник (на материале памятников севернорусских монастырей XVIII века) : автореф. дис. ... канд. филол. наук. М. 30 с.

Русанова С. В., 2012. Челобитная в кругу региональных документов XVIII века // История регионального текста: жанр - стиль - язык : монография / отв. ред. Т. П. Рогожникова. Омск : Вариант-Омск. С. 56-73.

Русанова С. В., 2016. Термины челобитная и промение в законодательных актах XVIII века //АCТА LINGUISTICAPETROPOLITANA. Труды Института лингвистических исследований РАН / отв. ред. Н. Н. Казанский. Т. 12, № 3. СПб. : Наука. C. 705-716.

Трофимова О. В., 2002. Жанрообразующие особенности русских документов XVIII в. (на материале тюменской деловой письменности 1762-1796 гг.) : дис. ... д-ра филол. наук. Тюмень. 519 с.

Юнаковская А. А., 2014. Становление и развитие жанра «письменное прошение» (на материале сибирских архивов) // Жанры речи. № 1-2 (9-10). C. 102-106.

\section{ИСТОЧНИКИ И СЛОВАРИ}

Вейсман - Вейсман Э. Немецко-латинский и руский лексикон : Купно с первыми началами рускаго языка к общей пользе / Имп. Академии наук ; пер. на рус. яз. И. И. Ильинского, И. П. Сатарова, И. С. Горлицкого. St. Petersburg : Gedr. in der Kayserl. Acad. der Wissenschafften Buchdruckerey, 1731. $788 \mathrm{c}$.

КС СРЯ XVIII - Картотека «Словаря русского языка XVIII века» / Институт лингвистических исследований РАН.

Новой лексикон - Новой лексикон на францусском, немецком, латинском, и на российском языках / пер. С. Волчкова. СПб. : При Имп. Акад. наук, 1755. Ч. 1. 1066 c.
ПЗДП - Памятники забайкальской деловой письменности XVIII века / под ред. А. П. Майорова ; сост. А. П. Майоров, С. В. Русанова. УланУдэ : Изд-во Бурят. гос. ун-та, 2005. 260 с.

ПСЗ - Полное собрание законов Российской империи : в 45 т. T. III-XII, XIV-XVI, XVIII, XXIXXIII. СПб. : В Типографии II Отделения Собственной Е. И. В. Канцелярии, 1830-1849. URL: http://www.nlr.ru/e-res/law r/content.htm.

CAP - Словарь Академии Российской : в 6 т. СПб. : При Имп. Акад. наук, 1789-1794.

СРЯ XVIII - Словарь русского языка XVIII века. Вып. 1. Л. : Наука, 1984.; Вып. 16. СПб. : Наука, 2006. URL: http://iling.spb.ru/vocabula/xviii/pdf/ scanned/10.pdf.

СРЯВСЗ XVIII - Словарь русского языка XVIII века: Восточная Сибирь. Забайкалье / сост. А. П. Майоров. М. : Азбуковник, 2011. 584 с.

\section{REFERENCES}

Volkov S.S., 1974. Leksika russkikh chelobitnykh XVII veka. Formulyar, traditsionnye etiketnye $i$ stilevye sredstva [Lexicon of the Russian Petitions of the $17^{\text {th }}$ Century. Form, Traditional Etiquette and Style Means]. Leningrad, Izd-vo Leningradskogo universiteta. $164 \mathrm{p}$.

Vykhrystyuk M.S., 2008. Tobolskaya pismennost XVIIXVIII vv. $v$ aspekte lingvisticheskogo istochnikovedeniya i istoricheskoy stilistiki : dis.... d-ra filol. nauk. [The Tobolsk Writing of the $17^{\text {th }}-18^{\text {th }}$ Centuries in Aspect of Linguistic Source Study and Historical Stylistics. Dr. philol. sci. diss.]. Chelyabinsk. 558 p.

Gauch O.N., 2013. Zhanrovoe svoeobrazie organizatsionno-rasporyaditelnykh dokumentov delovoy pismennosti XVIII v. (na materiale TFGATO) [Genre Diversity of Organizational Administrative Documents of XVIII Century's Formal Writing (Based on Materials of Tobolsk Branch of Tyumen Region State Archive)]. Nauchnyy Dialog [Scientific Dialogue], no. 5 (17), pp. 221-233.

Glukhikh N.V., 2008. Delovoy epistolyarnyy tekst kontsa XVIII - nachala XIX v. na Yuzhnom Urale: lingvistika teksta [Business Epistolary Text of the Late $18^{\text {th }}$ - the Early $19^{\text {th }}$ Century in the South Ural Rgion: Text Linguistics]. Chelyabinsk, Poligraf-Master Publ. 169 p.

Gorban O.A., Sheptukhina E.M., 2013. Regionalnye dokumenty XVIII veka: aspekty lingvisticheskogo opisaniya [Regional Documents of the XVIII ${ }^{\text {th }}$ Century: Aspects of Linguistic Analysis]. Vestnik Volgogradskogo gosudarstvennogo universiteta. Seriya 2, Yazykoznanie [Science Journal of 
Volgograd State University. Linguistics], no. 3 (19), pp. 76-84.

Koposov L.F., 2000. Severnorusskaya delovaya pismennost XVII-XVIII vv. (orfografiya, fonetika, morfologiya) [Northern Russian Business Writing of the $17^{\text {th }}-18^{\text {th }}$ Centuries (Spelling, Phonetics, Morphology)]. Moscow, Narodnyy uchitel Publ. 287 p.

Kosov A.G., 2004. Evolyutsiya dokumentnykh zhanrov XVIII veka: $\mathrm{Na}$ materiale rukopisnykh $i$ pechatnykh tekstov Obyedinennogo gosudarstvennogo arkhiva Chelyabinskoy oblasti : dis. ... kand. filol. nauk [Evolution of Document Genres of the $18^{\text {th }}$ Century: On Material of Hand-Written and Printing Texts of the Joint State Archive of Chelyabinsk Region. Cand. philol. sci. diss.]. Chelyabinsk. 273 p.

Mayorov A.P., 2004. Prositelnye dokumenty XVIIXVIII vv. Lingvoistochnikovedcheskiy aspekt [Pleading Documents of the $17^{\text {th }}-18^{\text {th }}$ Centuries. Linguistic Source Study Aspect]. Palaeoslavica: International Journal for the Study of Slavic Medieval Literature, History, Language and Ethnology. Cambridge, Palaeoslavica, 12/2, pp. 198-213.

Mayorov A.P., 2006. Ocherki leksiki regionalnoy delovoy pismennosti XVIII veka [Sketches of Lexicon of Regional Business Writing of the $18^{\text {th }}$ Century]. Moscow, Azbukovnik Publ. 263 p.

Malysheva I.A., 1997. Pamyatniki delovoy pismennosti XVIII v. kak obyekt lingvisticheskogo istochnikovedeniya [Monuments to Business Writing of the $18^{\text {th }}$ Century as an Object of the Linguistic Source Study]. Khabarovsk, Izd-vo Khabarovskogo pedagogicheskogo universiteta. $182 \mathrm{p}$.

Nikitin O.V., 2000. Russkaya delovaya pismennost kak etnolingvisticheskiy istochnik (na materiale pamyatnikov severnorusskikh monastyrey XVIII veka) : avtoref. dis. ... kand. filol. nauk [Russian Business Writing as an Ethnolinguistic Source (On Material of Monuments of the North Russian Monasteries of the $18^{\text {th }}$ Century. Cand. philol. sci. abs. diss.]. Moscow. 30 p.

Rusanova S.V., 2012. Chelobitnaya v krugu regionalnykh dokumentov XVIII veka [Petition in a Circle of Regional Documents of the $18^{\text {th }}$ Century]. Istoriya regionalnogo teksta: zhanr - stil - yazyk: monografiya [History of the Regional Text: Genre - Style - Language: Monograph]. Omsk, Variant-Omsk Publ, pp. 56-73.

Rusanova S.V., 2016. Terminy chelobitnaya i proshenie v zakonodatelnykh aktakh XVIII veka [The Terms Chelobitnaja 'Humble Petition' and Proshenije 'Plea, Application, Solicitation' in Russian
Legislative Acts of the $18^{\text {th }}$ Century]. ACTA LINGUISTICA PETROPOLITANA. Trudy Instituta lingvisticheskikh issledovaniy RAN [Acta Linguistica Petropolitana. Transactions of the Institute for Linguistic Studies]. Saint Petersburg, Nauka Publ. vol. 12, no. 3, pp. 705-716.

Trofimova O.V., 2002. Zhanroobrazuyushchie osobennosti russkikh dokumentov XVIII v. (na materiale tyumenskoy delovoy pismennost $i$ 1762-1796 gg.) : dis. ... d-ra filol. nauk [Genre Forming Features of the Russian Documents of the $18^{\text {th }}$ Century (On Material of the Tyumen Business Writing of 1762-1796). Dr. philol. sci. diss.]. Tyumen. 519 p.

Yunakovskaya A.A., 2014. Stanovlenie i razvitie zhanra «pismennoe proshenie» (na materiale sibirskikh arkhivov) [The Formation and Development of the Genre "Written Request" (on the material of the Siberian Archives)]. Zhanry rechi [Speech Genres], no. 1-2 (9-10), pp. 102-106.

\section{SOURCES AND DICTIONARIES}

Veysman E. Nemetsko-latinskiy i ruskiy leksikon: Kupno s pervymi nachalami ruskago yazyka kobshchey polze [German-Latin and Russian Lexicon. With the First Principles of the Russian Language to the Common Good]. Saint Petersburg, Gedr. in der Kayserl. Acad. der Wissenschafften Buchdruckerey, 1731. $788 \mathrm{p}$.

Kartoteka «Slovarya russkogo yazyka XVIII veka» [Card File of the Dictionary of Russian of the $18^{\text {th }}$ Century]. Institute of Linguistic Researches of the Russian Academy of Sciences.

Volochkov S., transl. Novoy leksikon na frantsusskom, nemetskom, latinskom, i na rossiyskom yazykakh [New Lexicon in French, German, Latin, and Russian Languages]. Saint Petersburg, Pri Imperatorskoy Akademii Nauk, 1755, part. $1.1066 \mathrm{p}$.

Mayorov A.P., Rusanova S.V. Pamyatniki zabaykalskoy delovoy pismennosti XVIII veka [Monuments of the Transbaikal Business Writing of the $18^{\text {th }}$ Century]. Ulan-Ude, Izd-vo Buryatskogo Gosudarstvennogo Universiteta, 2005. $260 \mathrm{p}$.

Polnoe sobranie zakonov Rossiyskoy imperii : $v 45 t$. T. III-XII, XIV-XVI, XVIII, XXI-XXIII [Complete Collection of Laws of the Russian Empire in 45 Volumes. Vols. 3, 4, 5, 6, 7, 8, 9, 10, 11, 12, 14, 15, 16, 18, 21, 22, 23]. Saint Petersburg, V Tipografii II Otdeleniya Sobstvennoy E. I. V. Kantselyarii, 1830-1849. URL: http://www.nlr.ru/e-res/law_r/ content.htm. 
Slovar Akademii Rossiyskoy: v $6 t$. [Dictionary of the Russian Academy. In 6 Vols]. Saint Petersburg, Pri Imperatorskoy Akademii Nauk, 1789-1794.

Slovar russkogo yazyka XVIII veka [Dictionary of the Russian Language of the $18^{\text {th }}$ Century]. Leningrad, Nauka Publ., 1984, vol. 1; Saint
Petersburg, Nauka Publ., 2006, vol. 16. URL: http:/ /iling.spb.ru/vocabula/xviii/pdf/scanned/10.pdf. Mayorov A.P. Slovar russkogo yazyka XVIII veka: Vostochnaya Sibir. Zabaykalye [Dictionary of Russian of the $18^{\text {th }}$ Century: Eastern Siberia. Transbaikalia]. Moscow, Azbukovnik Publ., 2011.584 p.

\section{Information about the Author}

Svetlana V. Rusanova, Candidate of Sciences (Philology), Associate Professor, Department of Philology, Novosibirsk State Technical University, Prosp. K. Marksa, 20, 630073 Novosibirsk, Russia, rusanova@corp.nstu.ru,https://orcid.org/0000-0003-3451-6892

\section{Информация об авторе}

Светлана Владимировна Русанова, кандидат филологических наук, доцент кафедры филологии, Новосибирский государственный технический университет, просп. К. Маркса, 20, 630073 г. Новосибирск, Россия, rusanova@corp.nstu.ru, https://orcid.org/0000-0003-3451-6892 